\title{
THE CONTROL OF THE CONSTITUTIONALITY OF EUROPEAN UNION LAW BY MEANS OF CONSTITUTIONAL COMPLAINTS
}

\author{
Ilona Gradzka*
}

\begin{abstract}
The subject of this article is the institution of the constitutional complaint, which is analysed in connection with European integration. It should be noted that Poland's membership of the European Union has had a great influence, not only on the system of national law, but also on the jurisprudence of the Polish Constitutional Tribunal; therefore considerations are carried out here mainly in relation to the Constitutional Tribunal. In examining the issue of the constitutional complaint, the following assumptions may be stated. First, the constitutional-complaint procedure, is in fact, the examination of the compliance of legal norms with the Constitution, any deviation being related to the entities initiating proceedings before the Constitutional Tribunal, Article 191(1)(6), of the Constitution $^{1}$, and to the material scope of the complaint, as determined in Article 79 of the Constitution. Second, there is no doubt that the constitutional complaint can become an important legal instrument shaping the jurisprudence of the Polish Constitutional Tribunal, which has to face constitutional issues related to European integration ${ }^{2}$. Following the example of the practice of other Member States,
\end{abstract}

Dr. Ilona Grądzka, Assistant Professor, Faculty of Law, Canon Law and Administration, The John Paul II Catholic University of Lublin; correspondence address: Al. Racławickie 14, 20-950 Lublin, Poland; e-mail: ilonag@kul.pl; https://orcid.org/ 0000-0003-0127-4970.

1 The Constitution of the Republic of Poland, Journal of 2 April 1997, Journal of Law 1997, No. 78, item 483, as amended.

2 The literature on the subject indicates that the membership of nation States of the European Union obliges constitutional courts to act in the field of integration. Their 
e.g. Germany, the Tribunal may use the institution of the constitutional complaint as a means of controlling the compliance of the secondary law of the European Union with the Constitution of the Republic of Poland.

Keywords: Constitutional Tribunal, constitution, constitutional complaint, legal system

\section{INTRODUCTION}

The constitutional complaint can be defined as a system serving the entities required in the Constitution to protect, by way of specific proceedings before a constitutional court, their rights contained in the Constitution in the event of their infringement by organs of public authority ${ }^{3}$. Depending on the specific model of the constitutional complaint adopted in a given nation State, broad and narrow models are distinguished. The narrow model of the constitutional complaint refers to its material scope, and may concern the legal norm on the basis of which the final decision or judicial decision concerning an individual has been issued. The second model, which adopts a wide material scope of the constitutional complaint, allows complaints both against acts of the application of the law (court decisions, administrative decisions), and against normative acts ${ }^{4}$.

task is to set the boundaries and conditions for the integration process. Jurisprudence in this area is referred to as acquis constitutionnel. Cf. Aleksandra Kustra, "Model skargi konstytucyjnej jako czynnik kształtujący orzecznictwo sądów konstytucyjnych w sprawach związanych z członkostwem państwa w Unii Europejskiej," Państwo i Prawo, no. 3 (2015): 35.

3 Bogusław Banaszak, Prawo konstytucyjne (Warsaw: C.H. Beck, 2008), 493.

4 The division into broad and narrow models of complaints is quite general, as there are certain differences in individual States, e.g. a narrow material scope can concern acts of the application of the law, and this is characteristic of the Czech Republic, Slovakia, and Slovenia; complaints directed exclusively against normative acts occur in Belgium, Latvia, Poland, and Hungary. A broad material scope of the constitutional complaint allowing complaints against acts of application of the law (court decisions, administrative decisions), as well as normative acts, is characteristic of Austria, Spain, and Germany. Cf. Aleksandra Kustra, Kelsenowski model kontroli konstytucyjności prawa a integracja europejska. Studio wptywu (Toruń: Wydawnictwo UMK, 2015), 153 et seq.; The widest-possible material scope of the complaint, also allowing complaints about the inaction of State authorities, 
The Polish model of the constitutional complaint, due to its narrow material scope, allows the Constitutional Tribunal (hereinafter the CT) only to examine the compliance of normative acts with the Constitution $^{5}$. The jurisprudence of the Federal Constitutional Court (hereinafter the FCC) is an example of the implementation of the constitutional complaint in a very-broad sense, as can be seen in the judgment made by the FCC in the context of a constitutional complaint concerning the EU Treaties, the Maastricht Treaty ${ }^{6}$, or the Lisbon Treaty ${ }^{7}$. It is stressed that the FCC has opened the way for individuals to challenge by means of constitutional complaint the provisions of subsequent treaties and agreements concluded within the European Union (hereinafter the UE) ${ }^{8}$. The jurisprudence of the FCC confirms the strong position of the constitutional complaint as a legal remedy within the German legal system, in which there are also attempts to use the constitutional complaint to block political decisions related to participation in the integration process 9 . The Polish CT cannot boast of as extensive a jurisprudence issued in the mode of the constitutional complaint as its German counterpart, especially in European cases. However, the judgment of 16 November 2011, SK 45/09 ${ }^{10}$, shows how European integration also influences the jurisprudence of the Polish CT. The institution of the constitutional complaint has enabled

is in force in Germany. Cf. Marta Derlatka, Skarga konstytucyjna w Niemczech (Warsaw: Wydawnictwo Sejmowe, 2009).

5 Cf. Anna Łabno, "Skarga konstytucyjna jako środek ochrony praw człowieka. Przyczynek do dyskusji," Przeglad Prawa Konstytucyjnego, no. 4 (2012): 41.

6 Federal Constitutional Court, Judgment of 12 October 1993, 2 BvR 1234, 2 BvR 2159/92; Rainer Arnold, "Orzecznictwo Federalnego Trybunału Konstytucyjnego a proces integracji europejskiej," Studia Europejskie, no. 1 (1999): 1.

7 Federal Constitutional Court, Judgment of June 2009, 2 BvE 2/08, 2 BvE 5/08, 2 BvR 1010/08, 2 BvR 1022/08, 2 BvR 1259/08, 2 BvR 182/09.

8 Magdalena Bainczyk, Polski i Niemiecki Trybunat Konstytucyjny wobec cztonkostwa państwa w Unii Europejskiej (Wrocław: Wydawnictwo Uniwersytet Wrocławski, 2017), 114.

9 Aleksandra Kustra, Kelsenowski model kontroli konstytucyjności prawa a integracja europejska, 159 and 175 . The FCC responsibilities listed here should be regarded only as examples, and not as an exhaustive list.

10 Polish Constitutional Tribunal, Judgment of 16 November 2011, Ref. No. SK 45/09, Journal of Laws 2011, item 97. 
the Tribunal, with the appropriate interpretation of constitutional provisions, to examine the compliance of an act of secondary EU law with the Polish Constitution.

\section{THE POSITION OF SECONDARY EU LAW IN THE POLISH LEGAL SYSTEM}

The normative acts which make up the Polish legal system, although they have the same binding force, differ in their legal force, subject matter, and mode of their enactment ${ }^{11}$. The Constitution of the Republic of Poland designates a catalogue of such acts in Chapter III, entitled Sources of $L a w^{12}$. This catalogue has a hierarchical structure, at the top of which is the Constitution, followed by acts, ratified international agreements, regulations, acts of local law, and law enacted by international organisations, which are applied directly, and takes precedence in the case of conflicts with other acts (Article 91(3) of the Constitution).

Thus, if the Polish legal system consists of normative acts, then acts of secondary law of the EU are part of this system ${ }^{13}$. The Polish legal system has been to a certain extent harmonised with the provisions of EU law. However, this has not contributed to avoiding conflicts between these systems of law. Therefore, the question arises as to which body is authorised to resolve the conflict which has occurred. It is obvious that the control of the compliance of a norm of national law with regard to its compliance with the Constitution is carried out by the national constitutional court. On the other hand, the control of such a norm with regard to its compliance with EU law belongs indirectly to the Court of Justice

11 Grzegorz Leopold Seidler, Henryk Groszyk, and Antoni Pieniążek, Wprowadzenie do nauki o państwie i prawie (Lublin: Wydawnictwo UMCS, 2009), 164.

12 Sources of law also include Articles 235 and 234 of the Constitution of the Republic of Poland.

13 It is rather unanimously recognised in doctrine that regulations, directives and decisions are normative acts. Cf. Anna Chmielarz, "Kontrola konstytucyjności prawa pochodnego Unii Europejskiej," Przeglad Sejmowy, no. 4 (2012): 16-18; Bartłomiej Kurcz, Dyrektywy Wspólnoty Europejskiej $i$ ich implementacja do prawa krajowego (Kraków: Zakamycze, 2004), 37. 
of the EU (hereinafter the CJEU), (which issues binding interpretations of EU law), and directly to the national Court, which decides whether the result of the interpretation of EU law as indicated by the CJ accepts the pro-EU interpretation of a provision of national law, or whether it requires the national court to refuse to apply the national provision, and to rule on the basis of the EU-legal norm ${ }^{14}$.

The Constitution of the Republic of Poland does not grant the CT the right to control the constitutionality of secondary law. However, in its judgment of 11 May 2005, the Tribunal indicated that neither Article 90(1) nor Article 91(3) could constitute a basis for delegating to an international organisation (or its body) the authority to enact legal acts, or to make decisions which would be contrary to the Constitution of the Republic of Poland (para. 4.5 of the justification) $)^{15}$.

While the transfer of authority on the basis of Article 90 of the Constitution, and the possibility of control by the CT of such a transfer, do not raise any doubts, the issue of Article 91(3) is not entirely clear. Could it be that the Tribunal is giving itself a green light to control the constitutionality of secondary EU law? The Constitution of the Republic of Poland does not allow the CT to control secondary law in any place. Moreover, allowing the ongoing examination of acts of secondary EU law by the Tribunal would create an excessive risk of conflicts with the CJEU ${ }^{16}$. It should be added that treaties grant Member States certain legal instruments to

14 Aleksandra Kustra, "Odroczenie przez TK utraty mocy obowiązującej przepisu niezgodnego z prawem UE - glosa do wyroku TS z 19.11.2009 r. w sprawie Krzysztof Filipiak przeciwko Dyrektor Izby Skarbowej w Poznaniu, C-314/08," Europejski Przeglad Sądowy, no. 6 (2012): 38.

15 Polish Constitutional Tribunal, Judgment of 11 May 2005, Ref. No. K 18/04, Journal of Laws 2005, item 49.

16 Stanisław Biernat, "Glosa nr 2 do wyroku TK 11.05.2005," Kwartalnik Prawa Publicznego, no. 4 (2005): 193; Likewise Jan Barcz, "Glosa nr 1, Glosy do wyroku Trybunału Konstytucyjnego z 11.5.2005 r. (zgodność Traktatu akcesyjnego z Konstytucją RP) K 18/04," Kwartalnik Prawa Publicznego, no. 4 (2005): 176; Anna Wyrozumska, "Glosa nr 4. Umowy międzynarodowe w wyrokach Trybunału Konstytucyjnego dotyczących Traktatu o przystąpieniu do UE oraz ENA," Kwartalnik Prawa Publicznego, no. 4 (2005): 231. In a different view, Władysław Czapliński argues that for the purposes of the law of treaties, the concept of an international agreement extends to all documents related to that agreement, and thus there are no obstacles to interpreting the provision of 
control whether the adopted acts of secondary legislation fall within the authority granted to the EU.

\section{THE CONTROL OF SECONDARY EU LAW BY THE CONSTITUTIONAL TRIBUNAL}

At the outset of considerations, the question needs to be posed as to whether the legal acts established by EU institutions may be subject to control in the mode of constitutional complaints set out in Article 79 (1) of the Constitution. It follows from the systematic structure of the Constitution that the subject matter of the jurisdiction of the Tribunal has been specified in two articles of the Constitution, i.e. Articles 79 and 188 (1-3). Interesting reflections on the correlation of these Articles were made by the CT in the judgment of 16 November 2011, SK 45/09. The aim of the examination conducted by the CT was to determine whether the subject of constitutional complaints may only be the acts enumerated in Article 188 (1-3) of the Constitution, or other normative acts referred to in Article 79 of the Constitution (para. 1.2 of the justification). Therefore, the question arises as to whether Article 188 (1-3) of the Constitution exhaustively defines the catalogue of acts which can be controlled by the Tribunal. Or does it not, and Article 79 of the Constitution lists a separate authority of the Tribunal?

The Tribunal, in the indicated judgment of 16 November 2011, stated "(...) the material scope of normative acts, which can be subjected to control of compliance with the Constitution in proceedings initiated as a result of filing a constitutional complaint has been defined in Article 79 (1) of the Constitution in a manner autonomous and independent from Article 188 (1-3), because the examination of constitutional complaints constitutes a separate type of proceedings". (para. 1.2 of the justification). Quoting one of the representatives of the doctrine, "if it were meant

Article 188 of the Constitution extensively, "Glosa nr 3 do wyroku TKz dnia 11 maja 2005 r., K 18/04," Kwartalnik Prawa Publicznego, no. 4 (2005): 211. 
to be otherwise, Article 188 (5) of the Constitution would be completely redundant"17.

The Constitution in Article 188 (1-3) enumerates the types of normative acts subject to the control of the Tribunal in the mode of ex-post control. None of the enumerated acts may be included in the category of secondary EU law, as they are not acts enacted by the organs of the Republic of Poland ${ }^{18}$. Part of the doctrine rightly holds "the way the cognition of the Constitutional Tribunal is determined a limine does not exclude from its scope the acts of secondary EU law, as long as the examination of constitutionality would proceed by way of constitutional complaint. Given the fact that Article 188(5) refers to Article 79(1) of the Constitution, the notion of 'another normative act' used in the latter provision could have an autonomous meaning in relation to the normative acts enumerated in items 1-3 of this Article (188) "19. There is also no shortage of negative voices according to which acts of secondary EU law are not listed among the legal acts subject to the control of the CT (Article 188 of the Constitution) ${ }^{20}$.

17 Marek Zubik, ““Akt normatywny” jako przedmiot kontroli Trybunału Konstytucyjnego," Gdańskie Studia Prawnicze 31 (2014): 734.

18 Marzena Laskowska, "Dopuszczalność kontroli zgodności aktów pochodnego prawa UE z Konstytucją RP. W przeddzień rozstrzygnięcia Trybunału Konstytucyjnego,” Studia Prawnicze KUL, no. 2 (2011): 61.

19 After Marzena Laskowska, "Dopuszczalność kontroli zgodności aktów pochodnego prawa UE z Konstytucją RP. W przeddzień rozstrzygnięcia Trybunału Konstytucyjnego," 61; Krzysztof Wojtyczek, Przekazanie kompetencji państwa organizacjom międzynarodowym (Cracow: Wydawnictwo Uniwersytetu Jagiellońskiego, 2007), 326-327. As Marcin Wiącek rightly notes, constitutional complaints and legal questions are means primarily serving the protection of an individual against the infringement of his or her freedoms or rights by means of an individual decision based on an unconstitutional legal norm. From this point of view, it should not matter what source the legal norm interfering with the status of an individual derives from, "Glosa do postanowienia TK z dnia 17 grudnia 2009 r., U 6/08," Państwo i Prawo, no. 6 (2010), www.lex.pl, accessed January 21, 2021.

20 Cf. Kazimierz Działocha, “Uwagi do art. 91 Konstytucji RP,” in Konstytucja RP. Komentarz, Vol. III (Warsaw: Wydawnictwo Sejmowe, 2003), 8; Jan Galster and Agnieszka Knade-Plaskacz, "Glosa do wyroku Trybunału Konstytucyjnego z dnia 16 listopada 2011 r. (sygn. Akt SK 45/09),” Przegląd Sejmowy, no. 6 (2012): 133. 
These acts are not listed in Article 87 of the Constitution, and are not normative acts ${ }^{21}$.

The author is of the opinion that the constitutional complaint has been detailed in a separate article of the Constitution for a reason, and in doing so it determined in an autonomous and exhaustive manner, the scope of the provisions subject to appeal. The Constitutional Tribunal, in its verdict of 11 May 2005, clearly emphasised "the norms of the Constitution in the field of individual rights and freedoms set a minimum and impassable threshold, which may not be lowered or questioned as a result of the introduction of Community regulations". It is clear that in the system of domestic law no normative acts should be in force which are not subject to the cognition of the CT.

\section{THE SUBJECTS OF CONSTITUTIONAL COMPLAINTS}

The Constitution indicates that constitutional complaints may be based on a statute or another normative act, on the basis of which a court or a public-administration body has made a final decision about freedoms or rights, or about the obligations of the complainant as set out in the Constitution. The article in question refers to a normative act, that is an act including in its content norms of an abstract and general nature. It seems that the subject of control in the mode of constitutional complaints should be understood more broadly than the "provision of law" as

21 After Małgorzata Masternak - Kubiak, "Dyskusja," in Stosowanie prawa międzynarodowego i wspólnotowego w wewnętrznym porządku prawnym Francji i Polski, ed. Mirosław Granat (Warsaw: Wydawnictwo Sejmowe, 2007), 101; Jan Barcz goes on to say, that, alternatively, "one could only consider filing a constitutional complaint against an Act by virtue of which consent to ratification of an international agreement by the President of the Republic of Poland is expressed. This route would, however, be closed, if the consent to ratify an international agreement was expressed - as in the case of the Treaty of Accession - by virtue of a decision of the sovereign expressed in a nationwide referendum", "Glosa nr 1, Glosy do wyroku Trybunału Konstytucyjnego z 11.5.2005 r. (zgodność Traktatu akcesyjnego z Konstytucją RP) K 18/04," 181. 
contained in Article $188(1-3)$ of the Constitution ${ }^{22}$. Such a thesis is justified by the specific nature of constitutional complaint, the aim of which is the protection of individual rights and freedoms. This was stressed by the CT in its decision of 21 September 2006, SK 10/06, in which it described this constitutional procedure as the last chance to assert the rights and freedoms infringed by the application of the provision challenged in the complaint ${ }^{23}$.

In the commented-on judgment of 16 November 2011, the Tribunal recognised that the regulation of the European Union was "another normative act" within the meaning of Article 79(1) of the Constitution, and thus could constitutes the subject of a constitutional complaint. In deciding on the question of the "normative act", the Tribunal indicated that such an act in the understanding of Article 79(1) of the Constitution might not only be a normative act issued by one of the Polish bodies, but also - on meeting further conditions - an act issued by an organ of an international organisation of which Poland is a member. This applies first and foremost to acts which belong to the law of the European Union, enacted by the institutions of this organisation. These acts, as the Tribunal points out, are part of the legal order in force in Poland, and determine the legal situation of an individual (paragraph 1.3 of the justification).

The Tribunal treats EU regulations as normative acts, on the basis of which a court or public-administration body makes a final decision on freedoms or rights, or on the obligations of individuals, as set out in the Constitution.

\section{THE EFFECTS OF JUDGMENTS BY THE CONSTITUTIONAL TRIBUNAL}

The Constitution of the Republic of Poland only applies to acts of Polish law in the case in which the effect of declaring an act unconstitutional

22 After Marek Safjan and Leszek Bosek, eds., Konstytucja RP. Vol. 1 (Warsaw: C.H. Beck, 2016), 1833; Marek Zubik, “"Akt normatywny” jako przedmiot kontroli Trybunału Konstytucyjnego,” 734.

23 Polish Constitutional Tribunal, Judgment of 21 September 2006, Ref. No. SK 10/06, Journal of Laws 2006, item 117. 
is the loss of the binding force of the normative $\mathrm{act}^{24}$. The CT, in a decision of 21 March 2000 (K 4/99) $)^{25}$, stated that the direct effect of a judgment of the CT on the inconsistency of a normative act (specific provisions or norms) with the Constitution was the loss of the binding force of provisions inconsistent with the Constitution on the date of entry into force of the Tribunal's judgment, or on another date specified by the Tribunal. The normative act or its part (specifically designated provisions), deemed by the Tribunal to be inconsistent with the Constitution, are removed from the legal order, and cease to be an element thereof. The judgment by the CT on the inconsistency of a normative act, or part thereof, with the Constitution, results in the absolute, unconditional, and direct abolition (annulment) of the provisions (norms) indicated therein (item 3 of the justification). In the case of acts of EU law, such an effect would be impossible, as the binding force of such acts is not determined by the Polish authorities. The only consequence of the CT judgment would be to deprive acts of secondary EU law of the applicability by the Polish authorities, and of having legal effect in Poland. The Tribunal points out that as a result of the judgment, such a state of affairs is unacceptable, and could become the basis for instituting proceedings against Poland before the CJEU (SK 45/09). The Tribunal emphasises that the ruling on the inconsistency of the EU law with the Constitution should be of an $u l$ tima ratio nature, and should occur only when all other ways of resolving the conflict with the norms belonging to the legal order of the EU have failed (e.g. making changes to the Constitution ${ }^{26}$, influencing changes to EU regulations, making the decision to withdraw from the EU). However,

24 Article 190 (1) and (3) of the Constitution.

25 Polish Constitutional Tribunal, Judgment of 21 March 2000, Ref. No. K 4/99, Journal of Laws 2000, item 65.

26 As the authors of the gloss to the judgment of the Constitutional Tribunal rightly point out, a solution in the form of amending the Constitution of the Republic of Poland should be excluded, since the Constitutional Tribunal decided on the unconstitutionality of a given act of secondary law due to the breach of constitutional rights and freedoms, and not in order to lower the standard of protection of these rights by amending the Constitution of the Republic of Poland, Piotr Bogdanowicz and Paweł Marcisz, "Szukając granic kontroli. Glosa do wyroku TK z dnia 16 listopada 2011 r., SK 45/09,” Europejski Przeglad Sądowy, no. 9 (2012), www.lex.pl, accessed January 21, 2021. 
should the Tribunal rule that certain norms of secondary Union law are inconsistent with the Constitution, action to remedy the situation should be taken immediately. The Tribunal indicates that the effects of such a ruling should be postponed, pursuant to Article 190(3) of the Constitution ${ }^{27}$. The Tribunal, referring to the judgment of 27 April 2005 (P 1/05) ${ }^{28}$ concerning the European Arrest Warrant, justified this by the fact that in that judgment it postponed the loss of binding force of the act implementing EU law, referring in particular to the constitutional obligation of Poland to comply with international law binding it, as well as the community of systemic principles binding Poland and the other EU Member States, ensuring the proper administration of justice (para. 2.7 of the justification).

It needs to be emphasised, however, that in the referenced judgment of 27 April 2005 the period of postponement was intended for the Polish legislator (it concerned the implementing act), in order to amend the Constitution of the Republic of Poland, and remove the state of inconsistency with $\mathrm{EU} \mathrm{law}^{29}$. In the judgment of 16 November 2011 the situation arose in which the issue was the inconsistency of certain norms of secondary EU law with the Constitution, i.e. the appropriate solution would be to undertake actions aimed at introducing changes to EU regulations, i.e. actions whose effectiveness depends on the will of entities other than the Polish State ${ }^{30}$.

At this point the following question seems appropriate. What about an act of secondary legislation after the ineffective expiry of the period for which the effects of the Tribunal's decision had been postponed?

27 In the doctrine it is noted "since in Article 190(3) of the Constitution the legislator expressis verbis determined that the effect of the entry into force of a judgment of the CT is the loss of the binding force of a normative act, it is debatable whether the Tribunal is entitled to give this notion a different meaning in relation to a given category of acts". Tomasz Jaroszyński, "Glosa do wyroku TK z dnia 16 listopada 2011 r., SK 45/09. Dopuszczalność kontroli zgodności unijnego prawa pochodnego z Konstytucją, Państwo i Prawo, no. 9 (2012): 9, www.lex.pl, accessed January 21, 2021.

28 Polish Constitutional Tribunal, Judgment of 27 April 2005, Ref. No. P 1/05, Journal of Laws 2005, item 42.

29 After Piotr Bogdanowicz and Paweł Marcisz, "Szukając granic kontroli. Glosa do wyroku TK z dnia 16 listopada 2011 r., SK 45/09”.

30 Ibidem. 
According to the position of the CT, an unconstitutional act cannot be applied by the Polish authorities and has no legal effect in Poland. The consequences of such an action could be detrimental to the Polish State, as the Treaty on the Functioning of the $\mathrm{EU}^{31}$ provides the Commission with certain legal instruments it may use if Poland breaches its obligations under treaties ${ }^{32}$.

The obligation resting with the Polish State to comply with EU law is evident. However, the superior legal force of the Polish Constitution in the system of domestic law should also be borne in mind. The CT emphasised that on the basis of Article 8, the Constitution is the supreme law of the Republic of Poland, and therefore the Tribunal is obliged to understand its position in such a way that in matters of fundamental, systemic, significance it retains the position of the "court of last resort" with regard to the Polish Constitution. The CT draws attention to the need to distinguish between, on the one hand, the examination of the compliance of acts of secondary EU law with the treaties, that is with the primary law of the Union, and on the other hand, the examination of their compliance with the Constitution. This is why the Tribunal pronounced that the body which ultimately decides on the compliance of EU regulations with the treaties is the Court of Justice of the EU, and on the compliance with the Constitution it is the Constitutional Tribunal (SK 45/09, para. 2.3 of the justification). Excluding the situation of competition between these two bodies, the CT noted that it was not only a matter of eliminating the phenomenon of duplication between the two courts or dualism in adjudicating on the same legal problems, but also dysfunctionality in relations between the EU and the Polish legal order (SK 45/09, para. 2.3 of the justification).

It follows from the statements of the CT that the consequence of inconsistency of a norm of EU law with the Polish Constitution may not mean the derogation of this act, but only the impossibility to apply it in internal law. It should be stressed, however, that such a judgment will not

31 The Treaty on the Funcioning of the European Union, OJ EU 202/47 of 7 June 2016 (consolidated version, hereinafter: TFEU).

32 Art. 258 of the TFEU. 
have a direct effect on external relations ${ }^{33}$. A rather-general statement of the CT regarding the consequences of its verdict stating the unconstitutionality of an act of secondary EU law suggests that an amendment to the Constitution of the Republic of Poland would be the appropriate solution. It seems that the considerations of the radical consequences of a CT judgment are only of a theoretical nature.

\section{CONCLUSIONS}

The CT has for the first time exercised control over acts of secondary law in the mode of a specific regulation. At the same time, it chose not to enter into dialogue with the CJEU. In the case in question, it concluded that there was no need to submit to the CJEU a request for a preliminary ruling, as the CT had no doubts as to the compatibility of the contested regulation with primary EU law.

Ultimately, the Tribunal stated that the material scope of normative acts, which can be subjected to the control of compliance with the Constitution in the proceedings initiated as a result of filing a constitutional complaint, had been defined in Article 79 (1) of the Constitution in a manner autonomous and independent from Article 188 (1-3). The author, unlike the CT, is of the opinion that the examination of constitutional complaints does not constitute a new type of proceeding, which emanates, in the opinion of the Tribunal, from the systematic structure of the Constitution, from which it interprets several types of proceedings (before the Tribunal), and, in one of them, unlike the others, it defined the proceeding in which constitutional complaints were to be examined. One cannot agree with the standpoint of the CT here; a complaint is aimed at protecting the freedoms and rights of the individual, which it does by examining the compliance of a normative act with the Constitution. This means the examination of the constitutionality of the act, which is no different from the responsibility of the Tribunal as indicated

33 Aleksandra Syryt, Oddziatywanie prawa międzynarodowego na sądownictwo konstytucyjne w Polsce-perspektywa konstytucyjna (Warsaw: Wydawnictwo Instytutu Wymiaru Sprawiedliwości, 2019), 162. 
in Article 188 (1-3) of the Constitution. The reference to Article 79 in Article 188 (5) of the Constitution confirms the authority of the CT to adjudicate in the mode of the constitutional complaint, and at the same time is an argument confirming the distinctness of its material scope. Article 191 (1) (6) of the Constitution, in conjunction with Article 79, defines the circle of entities which may initiate proceedings in this matter.

It is a very good thing that the CT was able to examine the constitutionality of an act of EU law in the course of constitutional complaints. So far, it has only ruled on EU law, but in relation to ratified international agreements under the procedure specified in Article 188 of the Constitution $^{34}$, whereas constitutional complaints have broadened the scope of the Tribunal's jurisdiction. It was for the only instance where constitutional complaints and only complaints were an act of UE secondary law.

The statement of the CT concerning the consequences of judgments in the event of a ruling on inconsistency with the Constitution of the norms of secondary EU law leaves something to be desired. It is probably impossible to formulate a specific standpoint on this issue, given the obligations resting on Poland as a result of its membership of the EU. However, should the incompatibility of secondary EU law entail a change to the Polish Constitution? The Tribunal referred to its statement in the judgment of 11 May 2005, in which it stated that a conflict between EU law and the provisions of the Polish Constitution cannot lead to the recognition of the primacy of a EU norm in relation to a constitutional norm. In such a situation, according to the Tribunal, it would be up to the Polish legislator to decide whether to amend the Constitution, or to effect changes to EU regulations, or - ultimately - to decide to withdraw from the EU (justification, para. 6.4). Ultimately, such a conflict will most likely end with an amendment of the Constitution of the Republic of Poland ${ }^{35}$. The CT was more decisive in its verdict of 24 November 2010 on the Treaty of Lisbon, in which it stated “(...) the preservation

34 The two most- important judgments in this respect are: Polish Constitutional Tribunal, Judgment of 11 May 2005, Ref. No. K 18/04, Journal of Laws 2005, item 49 and Polish Constitutional Tribunal, Judgment of 24 November 2010, Ref. No. K 32/09, Journal of Laws 2010, item 108.

35 This also happened in 2006, when Article 55 of the Constitution was amended by Article 1 of the Act of 8 September 2006, Journal of Laws 2006, No. 200, item 1471; 
of the supremacy of the Constitution in the conditions of European integration must be considered to be tantamount to the preservation of state sovereignty (...), and Poland's accession to the European Union changes the perspective on the principle of the supreme legal force of the Constitution (its primacy), but does not constitute a questioning of it" (para. 1.3 of the justification). This means that in the situation of European integration, the supremacy of the Constitution of the Republic of Poland should be perceived differently, as its provisions are covered by the principle of pro-EU interpretation of the law, i.e. European law has gained influence on the shaping of constitutional principles ${ }^{36}$.

Thus, if the rights of the individual are under a special "protective umbrella", and since constitutional complaints are an extraordinary means of protecting constitutional freedoms and rights, while the Constitutional Tribunal is the "court of the last word" with regard to the Polish Constitution, then the control initiated by way of constitutional complaints may be perceived as an instrument protecting the supremacy of the Constitution of the Republic of Poland. This thesis may be confirmed by the verdict of the CT of 11 May 2005, in which it stated that the norms of the Constitution in the field of individual rights and freedoms set a minimum and impassable threshold which cannot be lowered or questioned as a result of the introduction of Community regulations. The Court stressed the guarantee role of the Constitution, from the point of view of the protection of rights and freedoms explicitly set out therein, and this in relation to all entities active in the sphere of its application.

To date, the Constitutional Tribunal has expressed its opinion on EU law, but in relation to ratified international agreements in the mode of Article 188 of the Constitution, whereas the interpretation of the provisions of the Constitution of the Republic of Poland has made it possible to examine, in the mode of the constitutional complaint (and only in this mode), the constitutionality of directly applicable norms of secondary EU law. Following the jurisprudential practice, in cases concerning

The amendment of the Constitution occurred due to the incompatibility of the European Arrest Warrant with Article 55 of the Constitution of the Republic of Poland.

36 Cf. Mirosław Granat, "Tożsamość Konstytucji," in Zmieniać Konstytucję Rzeczypospolitej czy nie zmieniać?, ed. Dariusz Dudek (Lublin: Wydawnictwo KUL, 2017), 52. 
European integration, of its German counterpart, the CT should more frequently, and with greater certainty, use the constitutional complaint to examine the compliance of the norms of EU law with the Polish Constitution.

\section{REFERENCES}

Bogusław, Banaszak. Prawo konstytucyjne. Warsaw: C.H. Beck, 2008.

Barcz, Jan. "Glosa nr 1, Glosy do wyroku Trybunału Konstytucyjnego z 11.5.2005 r. (zgodność Traktatu akcesyjnego z Konstytucją RP) K 18/04.” Kwartalnik Prawa Publicznego, no. 4 (2005): 169-184.

Bainczyk, Magdalena. Polski i Niemiecki Trybunat Konstytucyjny wobec cztonkostwa państwa w Unii Europejskiej. Wrocław: Wydawnictwo Uniwersytet Wrocławski, 2017.

Biernat, Stanisław. "Glosa nr 2 do wyroku TK 11.05.2005." Kwartalnik Prawa Publicznego, no. 4 (2005): 185-206.

Bogdanowicz, Piotr, and Paweł Marcisz. "Szukając granic kontroli. Glosa do wyroku TK z dnia 16 listopada 2011 r., SK 45/09. Szukając granic kontroli." Europejski Przeglad Saqdowy, no. 9 (2012): 47-52.

Chmielarz, Anna. "Kontrola konstytucyjności prawa pochodnego Unii Europejskiej." Przeglad Sejmowy, no. 4 (2012): 9-32.

Czapliński, Władysław. "Glosa nr 3 do wyroku TK z dnia 11 maja 2005 r., K 18/04.” Kwartalnik Prawa Publicznego, no. 4 (2005): 207-222.

Derlatka, Marta. Skarga konstytucyjna w Niemczech. Warsaw: Wydawnictwo Sejmowe, 2009.

Działocha, Kazimierz. “Uwagi do art. 91 Konstytucji RP.” In Konstytucja RP. Komentarz, Vol. III. Warsaw: Wydawnictwo Sejmowe, 2003.

Granat, Mirosław. “Tożsamość Konstytucji." In Zmieniać Konstytucję Rzeczypospolitej czy nie zmieniać?, edited by Dariusz Dudek, 43-64. Lublin: Wydawnictwo KUL, 2017.

Jaroszyński, Tomasz. "Glosa do wyroku TK z dnia 16 listopada 2011 r., SK 45/09. Dopuszczalność kontroli zgodności unijnego prawa pochodnego z Konstytucją." Państwo i Prawo, no. 9 (2012): 130-135.

Kurcz, Bartłomiej. Dyrektywy Wspólnoty Europejskiej i ich implementacja do prawa krajowego. Kraków: Wydawnictwo Zakamycze, 2004.

Kustra, Aleksandra. Kelsenowski model kontroli konstytucyjności prawa a integracja europejska. Studio wptywu. Toruń: Wydawnictwo UMK, 2015. 
Kustra, Aleksandra. "Model skargi konstytucyjnej jako czynnik kształtujący orzecznictwo sądów konstytucyjnych w sprawach związanych z członkostwem państwa w Unii Europejskiej.” Państwo i Prawo, no. 3 (2015): 34-56.

Kustra, Aleksandra. "Odroczenie przez TK utraty mocy obowiązującej przepisu niezgodnego z prawem UE-glosa do wyroku TS z 19.11.2009 r. w sprawie Krzysztof Filipiak przeciwko Dyrektor Izby Skarbowej w Poznaniu, C-314/08.” Europejski Przeglad Sądowy, no. 6 (2012): 34-40.

Laskowska, Marzena. "Dopuszczalność kontroli zgodności aktów pochodnego prawa UE z Konstytucją RP. W przeddzień rozstrzygnięcia Trybunału Konstytucyjnego." Studia Prawnicze KUL, no. 2 (2011): 59-85.

Łabno, Anna. "Skarga konstytucyjna jako środek ochrony praw człowieka. Przyczynek do dyskusji." Przeglad Prawa Konstytucyjnego, no. 4 (2012): 39-60.

Masternak-Kubiak, Małgorzata. "Dyskusja." In Stosowanie prawa międzynarodowego i wspólnotowego w wewnętrznym porządku prawnym Francji i Polski, edited by Mirosław Granat, 100-104. Warsaw: Wydawnictwo Sejmowe, 2007.

Safjan, Marek, and Leszek Bosek, eds. Konstytucja RP. Vol. 1. Warsaw: C.H. Beck, 2016.

Seidler, Grzegorz Leopold, Henryk Groszyk, and Antoni Pieniążek. Wprowadzenie do nauki o państwie i prawie. Lublin: Wydawnictwo UMCS, 2009.

Syryt, Aleksandra. Oddziatywanie prawa międzynarodowego na sąownictwo konstytucyjne w Polsce-perspektywa konstytucyjna. Warsaw: Wydawnictwo Instytutu Wymiaru Sprawiedliwości, 2019.

Wiącek, Marcin. "Glosa do postanowienia TK z dnia 17 grudnia 2009 r., U 6/08." Państwo i Prawo, no. 6 (2010): 122-127.

Wojtyczek, Krzysztof. Przekazanie kompetencji państwa organizacjom międzynarodowym. Kraków: Wydawnictwo Uniwersytetu Jagiellońskiego, 2007.

Wyrozumska, Anna. "Glosa nr 4. Umowy międzynarodowe w wyrokach Trybunału Konstytucyjnego dotyczących Traktatu o przystąpieniu do UE oraz ENA.” Kwartalnik Prawa Publicznego, no. 4 (2005): 223-231.

Zubik, Marek. "“'Akt normatywny” jako przedmiot kontroli Trybunału Konstytucyjnego." Gdan'skie Studia Prawnicze 31 (2014): 731-744. 
